\title{
PODRŠKA RAZVOJU TURIZMA KAO FAKTOR KONKURENTNOSTI SRBIJE KAO TURISTIČKE DESTINACIJE
}

\author{
Slobodan Čerović*, Dragoljub Barjaktarović, Miroslav Knežević \\ Univerzitet Singidunum, Danijelova 32, Beograd, Srbija
}

\begin{abstract}
Apstrakt:
Zahvaljujući prirodnim, geografskim, kulturno-istorijskim, klimatskim i drugim pogodnostima, Srbija ima veoma povoljne uslove za razvoj onih vidova turizma koji će u budućnosti opredeljivati pravce kretanja u međunarodnim relacijama i koji nude mogućnost za zadovoljavanje raznovrsnih potreba i zahteva savremenih turista. Uz to i dostignuti obim smeštajnih i drugih kapaciteta i ostale turističke infrastrukture daju dobru osnovu za značajnije valorizovanje tih resursa i za adekvatnije uključivanje naše zemlje u međunarodne turističke tokove, uključujući i brži razvoj domaćeg turizma. U radu je prikazano da turizam u Srbiji, po svim bitnim pokazateljima (devizna potrošnja, ostvareni turistički promet, zaposlenost, učešće u BDP-u, izvozu roba i usluga, investicijama i sl.), znatno zaostaje u odnosu na resursne i tržišne mogućnosti njegovog razvoja, što neminovno nameće potrebu za aktivnijom ulogom države u preduzimanju podsticajnih mera, kako bi njegova multiplikativna komponenta inicirala sveukupni privredni razvoj Srbije. Imajući to u vidu, osnovni cilj ovog rada jeste da ukaže na ključne aktivnosti države i drugih subjekata nadležnih za kreiranje i sprovođenje turističke politike koja će dovesti do valorizacije resursa kojima Srbija raspolaže.
\end{abstract}

\section{UVOD}

U proceni efekata budućeg razvoja turizma u Srbiji i njegovog uticaja na ukupni privredni razvoj mora se poći od očekivanih trendova u razvoju međunarodnog turizma, kvaliteta raspoloživih resursa, razvijenosti materijalne osnove i spremnosti zemlje da se ovoj delatnosti u privrednom sistemu i merama ekonomske politike obezbedi ravnopravan tretman sa ostalom izvoznom privredom. Srbija je do sada kroz više razvojnih dokumenta (Koncepcija razvoja turizma Srbije iz 1986. godine, Strategija razvoja turizma iz 1999. i 2006. godine, Prostorni plan Republike Srbije) definisala polazne osnove i strateške ciljeve razvoja turizma, koji su uglavnom ostajali nerealizovani.

Podsticanjem ove delatnosti, koja u globalnim okvirima po svim bitnim pokazateljima (brojem učesnika u međunarodnom turizmu, turističkoj potrošnji, učešćem u BDP, nacionalnom dohotku i broju zaposlenuh) zauzima jednu od vodećih pozicija u svetskoj privredi (Barjaktarović, 2013, str. 14), stvaraju se uslovi da Srbija, zahvaljujući bogastvu i raznovrsnošću resursa, geostrateškom položaju, gastronomskoj ponudi i gostoprimstvu, krene putem koji će joj obezbediti mesto na turističkoj pozornici interesantnoj i stranim i domaćim posetiocima.

Samo uz značajniju podršku koja bi otklonila postojeće barijere, Srbija bi znatno povećala inostrani i domaći turistički promet i potrošnju stranih turista i sa postojećim kapacitetima i raspoloživim turističkim proizvodom. Generatorska uloga turizma u privrednom razvoju, kao i poznati multiplikativni efekti koje stvara ovaj sektor privređivanja, doprineće i povećanju direktne i indirektne zaposlenosti, naročito u nedovoljno razvijenim područjima u svim delatnostima komplementarnim turizmu. Zato smatramo da je ovu delatnost neophodno uključiti u prioritetne pravce razvoja (Čerović, 2002, str. 171).

\section{USLOVI ZA RAZVOJ TURIZMA U SRBIJI}

Srbija, zahvaljujući prirodnim, geografskim, istorijskim, klimatskim i drugim pogodnostima, ima veoma povoljne uslove za razvoj onih vidova turizma koji će prema predvđanjima UNWTO u budućnosti predstavljati dominantne pravce kretanja u međunarodnim relacijama.

Osnovu za to čine poznati i već afirmisani planinski (Kopaonik, Zlatibor) i banjsko -zdravstveni centri (Vrnjačka, Bukovička, Niška, Kanjiža, Soko i druge banje); reke (Dunav, Tisa, Sava, Drina); brojna jezera (Đerdapsko, Palićko, Vlasinsko, Srebrno i dr.); Pešterski mesečev pejzaž, Đavolja varoš, Caričin grad u kome je rođen rimski car Justinijan, Medijana, Trajanova tabla i ostaci Trajanovog mosta, Lepenski vir i Vinča i još mnogo prirodnih bisera i drugih znamenitosti intetresantnih za turističku valorizaciju.

Ovu riznicu prirodne i kulturne baštine dopunjuju i brojni spomenici kulture, među kojima su najznačajniji manastiri Studenica, Sopoćani, Mileševo, Žiča, Stari Ras, Ravanica, fruškogorski i manastiri Ovčarsko - Kablarskog područja, Pećka patrijaršija, Dečani, Gračanica i još veliki broj znamenitosti. Deo ovih spomenika, zbog svoje izuzetne 
vrednosti, uvršten je u svetsku kulturnu baštinu i pod zaštitom je UNESCO-a (Stari Ras sa Sopoćanima, Studenica, Romulijana...). Ovi spomenici, svojim postojanjem, pričaju istoriju Srbije tokom poslednjih deset vekova (Barjaktarović, 2008, str. 61).

Ovome treba dodati i tradicionalno gostoprimstvo i bogatu i raznovrsnu trpezu sa velikim brojem prepoznatljivih nacionalnih jela i pića koja uz prepoznatljiv dizajn treba da prezentuju našu bogatu kulturno-istorijsku baštinu na međunarodnom turističkom tržštu, kao i brojne već afirmisane manifestacije, poput Guče i EXITA, koje značajno doprinose afirmaciji Srbije kao turističke destincije.

Ovako kvalitetna resursna osnova, uz dosignuti stepen razvijenosti materijalne osnove i očekivane trendove u međunarodnim turističkim kretanjima, opredeljuje i orijentaciju nosilaca turističke i poslovne politike Srbije prema onim oblicima turizma (turističkim proizvodima) koji treba da otvore vrata međunarodne turističke pozornice. U tom kontekstu, kao ključni turistički proizvodi Srbije izdvajaju se (Službeni glasnik RS, 2006):

1) gradski turizam (gradski odmori, manifestacije i dr.). Gradovi koji su posebno interesantni za inostrane posetioce su: Beograd, Novi Sad, Niš, Subotica, Sombor i Kladovo;

2) touring (kružna i linearna turistička putovanja) ture/ putevi - nacionalnih parkova, planina, klisura, pećina, srednjovekovnih manastira, dunavskih motiva, salaša, vina i gastronomije, biciklizma, pešačenja, jahanja, lova, ribolova i dr;

3) poslovni turizam + MICE (Meetings, Incentives, Conferences and Exibitions);

4) banjski turizam (zdravstveni/balneološki, klimatski i wellness/rekreativni);

5) planinski turizam (na visokim planinama, na srednjim i niskim planinama);

6) nautički i drugi vidovi turizma na vodi (reke, jezera, kanali);

7) događaji (Events);

8) ruralni turizam (agroturizam i kombinovani seoski turizam);

9) turizam specijalnih interesa (verski, rekreativno sportske, avanturističko - eksternističke i druge aktivnosti).

\subsection{Dostignuti nivo razvoja turizma Srbije}

Dostignuti nivo razvoja turizma, uprkos postojanju kvalitetne resursne osnove, po svim bitnim pokazateljima znatno zaostaje u odnosu na resursne i tržišne mogućnosti njegovog razvoja. U periodu od 1989. do 2010. godine turistički promet u Srbiji je opao prosečno godišnje 3,4\% u broju dolazaka i 2,9\% godišnje u broju noćenja. Drugim rečima, Srbija je 2010 ostvarila tek 54\% turističkog prometa iz 1989. godine mereno brojem noćenja (Unković \& Zečević, 2011, str. 407). U poslednjih 10 godina, prema zvaničnim podacima nadležnih institucija, turizam u užem smislu (sektor smeštaja i ishrane) učestvuje u bruto domaćem proizvodu između 1 i 1,5\%, pri čemu je najveći udeo bio uoči svetske ekonomske krize, najmanji u periodu od 2008. do 2011. godine, dok je u poslednje dve godine ponovo u porastu (RZS, 2014.). Može se proceniti da je danas ukupan doprinos tu- rizma privredi Srbije (sa direktnim i indirektnim efektima) oko $3 \%, 7 \%{ }^{1}$ u vrednosti izvozu roba i usluga, $29 \%$ vrednosti izvoza usluga, $1 \%$ u zaposlenosti direktno i 2,2\% indirektno, i oko 1\% u ukupnim investicijama (RZS, 2014).

Zabrinjava činjenica da se broj zaposlenih kontinuirano smanjuje, uprkos povećanju broja registrovanih privrednih subjekata, posebno u sektoru smeštaja i ishrane, što upućuje na zaključak da je u ovom sektoru privređivanja sivo tržište u značajnoj meri prisutno. Broj zaposlenih, prema zvaničnim staističkim podacima se sa 27.000 u 2006. godine smanjio na oko 20.000 direktno, odnosno ova delatnost upošljava što direktno, što indirektno oko 45.500 radnika (RZS). Ono što posebno zabrinjava je kontinuirani pad domačeg turističkog prometa, posebno od 2010. godine i smanjenje smeštajnih kapaciteta.

\subsubsection{Smeštajni kapaciteti}

Srbija danas raspolaže sa 43.657 smeštajne jedinice i 107.256 ležajeva, od čega 18.337 soba i 38.056 ležaja u osnovnim i 25.320 soba i 69.200 ležaja u komplementarnim smeštajnim kapacitetima (RZS, 2014). U okviru kategorisanih smeštajnih kapaciteta (356 objekata) hoteli (227) imaju dominantno mesto (63.66\%), čiji stepen iskoršćenosti je $25 \%$ na nivou republike, a u Beogradu nešto oko $38 \%$.

Tabela 1. Ukupan broj kategorisanih objekata prema vrsti i kategoriji/2014. god.

\begin{tabular}{cccc}
\hline $\begin{array}{c}\text { Vrsta } \\
\text { objekta }\end{array}$ & $\begin{array}{c}\text { Broj } \\
\text { objekata }\end{array}$ & $\begin{array}{c}\text { Br. sm. } \\
\text { jedinica }\end{array}$ & $\begin{array}{c}\text { BrOJ } \\
\text { ležaja }\end{array}$ \\
\hline Hoteli & 227 & 14604 & 24270 \\
\hline Apart hoteli & 8 & 381 & 1069 \\
\hline Garni hoteli & 94 & 1976 & 3162 \\
\hline Ukupno & 329 & 16.961 & 28591 \\
\hline Moteli & 13 & 301 & 498 \\
\hline Pansioni & 3 & 78 & 119 \\
\hline Tur.naselje & 4 & 215 & 384 \\
\hline Apartm. naselje & 1 & 26 & 107 \\
\hline Kampovi & 6 & 1055 & \\
\hline Ukupno & 356 & 17581 & 29609 \\
\hline
\end{tabular}

Izvor: Statistički godišnjak RZS 2014.

U ukupnoj hotelskoj ponudi (prema boju smeštajnih jedinica) dominiraju hoteli sa četiri $(29,20 \%)$ i tri zvezdice $(25,21 \%)$, zatim hoteli sa dve (14,9\%)(RZS, 2014).Struktura hotelskih kapaciteta je izmenjena u poslednjih nekoliko godina kada je došlo do izgradnje novih, i to prvenstveno sa $4^{\star}$, poznatih brendova (Radisson Blu, Crowne Plaza, Luxury Collection - Starwood, Falkeinsteiner, Holiday Inn, Best Western) i to pre svega, u Beogradu, Subotici, Novom Sadu i Nišu, kao i izgradnjom i adaptacijom jednog boja domaćih hotela (Grand, Mona, Izvor i dr.).

1 Izveštaj WTTC za 2014. godinu pokazuje da ukupno učešće turizma u BDP iznosi 6,1\%, a direktno (smeštaj, hrana i piće 2,1\% (WTTC, 2015) 


\subsubsection{Ostvareni turistički promet}

Broj turista koji posećuju Srbiju u periodu od 2000. do 2014. godine kreće se između 1.889.771 i 2.306.558 u 2007. godini, kada je registrovan i najveći broj turista u našoj zemlji od 1989. godine. U istom periodu broj ostvarenih noćenja domaćih i stranih turista kretao se između 6.173 i 7.334 miliona (tabela 2).

Tabela 2. Ukupan broj dolazaka i noćenja turista u Srbiji / 2000-2014. god.

\begin{tabular}{cccccccc}
\hline & & Dolasci turista & & \multicolumn{3}{c}{ Ostvarena noćenja turista } \\
\hline Godina & Ukupno & Domaći & Strani & Ukupno & Domaći & Strani \\
\hline 2000 & 2.166 .354 & 2.001 .128 & 165.226 & 7.688 .134 & 7.257 .041 & 431.093 \\
\hline 2005 & 1.989 .367 & 1.536 .321 & 453.158 & 6.499 .241 & 5.507 .138 & 992.087 \\
\hline 2006 & 1.889 .771 & 1.420 .929 & 468.842 & 6.407 .225 & 5.391 .913 & 1.015 .312 \\
\hline 2007 & 2.306 .558 & 1.610 .513 & 696.045 & 7.328 .692 & 5.853 .017 & 1.475 .675 \\
\hline 2008 & 2.266 .166 & 1.619 .672 & 646.494 & 7.334 .106 & 5.935 .219 & 1.398 .887 \\
\hline 2009 & 2.018 .466 & 1.373 .444 & 645.022 & 6.761 .715 & 5.292 .613 & 1.469 .102 \\
\hline 2010 & 2.000 .597 & 1.317 .916 & 682.681 & 6.413 .515 & 4.961 .359 & 1.452 .156 \\
\hline 2011 & 2.068 .610 & 1.304 .443 & 764.167 & 6.644 .738 & 5.001 .684 & 1.643 .054 \\
\hline 2012 & 2.079 .643 & 1.269 .676 & 809.967 & 6.484 .702 & 4.688 .485 & 1.796 .217 \\
\hline 2013 & 2.192 .435 & 1.270 .667 & 921.768 & 6.567 .460 & 4.579 .067 & 1.988 .393 \\
\hline 2014 & 2.192 .268 & 1.163 .536 & 1.028 .732 & 6.086 .275 & 3.925 .221 & 2.161 .054 \\
\hline
\end{tabular}

Izvor: Urađeno prema Statističkom godišnjaku RS, 2014.

Kao što se vidi iz predhodne tabele, Srbiju je u 2014. godini posetilo 2.192,268 turista (približno isti nivo u odnosu na prethodnu godinu) koji su osvarili 6.086.275 miliona noćnja, (7\% manje u odnosu na 2013. godinu). Domaćih turista bilo je $1,165.536$ ( $8 \%$ manje u odnosu na 2013.), što čini 53\% od ukupnog broja gostiju, a inostranih 1,028.732 ( $12 \%$ više u odnosu na 2013. godinu), odnosno $47 \%$ od ukupnog broja gostiju.

Od 6.086.275 noćenja domaći turisti ostvarili su 3.925.221 (14\% manje u odnosu na predhodnu godinu), što čini $64 \%$ od ukupnog broja ostvarenih noćenja, a inostrani 2,161.054 (9\% više), ili $36 \%$ od ukupnog broja ostvarenih noćenja (RZS, 2014).

Najveći broj dolazaka i noćenja domaćih turista ostvaren je u banjskim mestima (42\%), zatim slede planinska mesta (30\%) itd. Inostrani gosti najviše su boravili u Beogradu (51\%), Novom Sadu, Zlatiboru i Vrnjačkoj Banji.

U strukturi inostranih gostiju dominiraju turista iz regiona (45\%). Najveći broj noćenja ostvarili su turisti iz Bosne i Hercegovine (163.695 noćenja, što je za 5 \% više u odnosu na 2013. godinu). Od ostalih tržišta značajno učešće ostvaruju turisti iz Rusije 8.6\%, Italije 7.5\%, Nemačke 7.6\%, Turske 3.5\% (RZS, 2014).
Analizirajući ostvarene rezltate u turističkom prometu može se zakljčiti da u poslednjih nekoliko godina dolazi do značajnijeg slabljenja domaćeg turističkog prometa, što je rezultat pada životnog standarda, nedovoljno kvalitetne ponude i liberalizacije viznog režima. S druge strane, evidentno je povećanje broja stranih turista sa evropskih tržišta, što uz već tradicionalno visok nivo poseta iz zemalja regiona doprinosi značajnijem povećanju deviznog priliva po osnovu turizma.

\subsubsection{Ostvareni devizni priliv po osnovu turizma}

Najznačajniji efekti turizma pokazuju se kroz rast deviznog priliva (posebno posle 2007. godine kada je došlo do promene meodologije obračuna potrošnje stranih turista i posle 2011., kada inostrani turistčki promet ostvaruje značajniji rast), što se vidi iz sledeće tabele.

S druge strane, stanovnici Srbije za turistička putovanja u inostranstvo izdvajaju značajna sredstva. Prema nezvaničnim podacima Narodne banke Srbije i Nacionalne asocijacije turističkih agencija - YUTA - procenjuje se da je u 2014. godini broj naših građana koji su putovali u inostranstvo iznosio oko $1.350 .000 \mathrm{i}$ da su oni utrošili preko $1.1 \mathrm{mlrd}$. USD (YUTA, 2015).

Tabela br. 3: Devizni priliv u Srbiji 2005 - 2014. godine u mlrd. \$

\begin{tabular}{cccccccccccc}
\hline God & 2005 & 2006 & 2007 & 2008 & 2009 & 2010 & 2011 & 2012 & 2013 & 2014 \\
\hline$\$$ & 307 & 290 & 617,2 & 845 & 617,2 & 604,9 & 710,1 & 707,8 & 900,2 & 1050 \\
\hline Ind. & 1,39 & 0,94 & 2,13 & 1,37 & 0,73 & 0,98 & 1,17 & 1.00 & 1,27 & 1,17
\end{tabular}

Izvor: Obrađeno prema podacima Narodne banke Srbije (http://www.nbs.rs/internet/cirilica/90/sb.html) 


\section{CILJEVI DUGOROČNOG RAZVOJA TURIZMA REPUBLIKE SRBIJE}

U cilju potpunije valorizacije raspoloživih turističkih resursa u funkciji podsticanja privrednog rasta, regionalnog razvoja zemlje, povećanja zaposlenosti i boljeg pozicioniranja Srbije kao turističke destinacije na domaćem i međunarodnom turističkom tržištu, mogu se definisati sledeći cilje

1. Podsticanje ukupnog privrednog razvoja kroz potpunije korišćenje postojećih resursa ${ }^{2}$

Realizacija ovog cilja zahteva intenziviranje i kompletiranje turističke ponude, obogaćivanje novim sadržajima i podizanje nivoa kvaliteta usluga, prvenstveno u mestima koja su u određenoj meri turistički afirmisana. To je moguće ostvariti:

- unapređenjem i razvojem ukupne putne i druge infrastrukture (izgradnja započetih i planiranih najvažnijih magistralnih i regionalnih puteva, modermizacija železničkih putnih pravaca, unapređenje plovnog saobraćaja, rekonstrukcija postojeće i izgradnja nove vodovodne i kanalizacione mreže i dr. u skladu sa rešenjima iz Prostornog plana, Službeni glasnik RS, 2010a),

- podizanjem kvaliteta smeštajne ponude i izgradnjom novih hotelskih kapaciteta više i visoke kategorije, zelenih hotela, apartmanskih i turističkih naselja i rekreativnih sadržaja (spa, velnes, tenis tereni, golf i sl.), sa orijentacijom na korišćenje obnovljivih izvora energije, na područjima utvrđenim detaljnim urbanističkim planovima, s obzirom da isti garantuju kvalitetniju uslugu, veću popunjenost i bolje finansijske,

- standardizacijom usluga zasnovanom na međunarodnim standardima kvaliteta i uvođenjem savremenih informacionih tehnologija u svim segmentima poslovanja privrednih subjekata iz ove delatnosti,

- efikasnijim upravljanjem prirodnim i kulturnim resursima, zaštitom korisnika usluga, životne sredine i svih učesnika u lancu kreiranja i isporuke turistčkog proizvoda,

- intezivnijim promovisanjem kulturno - istorijskih, arheoloških i drugih prirodnih vrednosti i lokalnih običaja i tradicije.

2. Pozicioniranje Srbije kao turističke desinacije na međunarodno turističko tržište

Pozicioniranje Srbije kao turističke desinacije, u eri globalnog zaokreta prema novim i neistraženim destinacijama koje nude nove doživljaje i iskustva, zahteva:

- definisanje misije Srbije kao turističke destinacije, definisanje ciljeva budućeg razvoja inostranog turizma, primenu savremenih koncepcija (marketing, menadžment i dr.) u turističkoj privredi i jasno definisanje smernica preko kojih će i misija i ciljevi biti operacionalizovani (Čerović, 2007). Pri tome, poseb-

2 Jedan od brojnih ciljeva prethodnih strategija razvoja turizma bio je slično postavljen: Intenziviranje ukupnog razvoja kroz potpunije korišćenje postojećih kapaciteta (1999) i Podsticanje privrednog rasta, zapošljavanja i kvaliteta života stanovnika putem razvoja inostranog turizma (2006). Orijentacija prema ukupnom razvoju i domačeg i inostranog turizma opredeljuje i predložnu formulaciju ovog cilja. nu pažnju treba usmeriti na uspostavljanje savremenog sistema upravljanja na nivou turisičke destinacija i njihovu čvršću vezu sa Nacionalnom turističkom organizacijom, što zahteva promene strateškog marketing plana kojim će se na bolji način promovisati identitet Srbije.

- profilisanje onih proizvoda koji imaju šansu na inostranom turističkom ržištu. To su, pre svega, proizvodi povezani sa korišćenjem prirode i ekoturizma, zdravljem i rekreacijom, aktivnostima specijalnih interesa, ruralnim i kulturnim turizmom, rečnim krstarenjem, nautikom, kao i poslovnim turizmom i MICE, jer za ovim proizvodima u svetskim razmerama postoji veliko interesovanje.

Stvaranje povoljnijeg imidža i bolja pozicija na međunarodnom tržištu upućuje na upostavljanje mreže turističkih predstavništava na ciljim turističkim tržištima i značajnije povećanje turističkog budžeta, uz korišćenje savremenih sredstava i tehnologija promocije.

Realizaciju ovako postavljenih ciljeva moguće je ostvariti:

1. Uspostavljanjem privrednog ambijenta koji će stimuliativno delovati na razvoj turizma, kroz mere ekonomske politike koje će obezbediti da ova delatnost postane jedan od ključnih generatora ukupnog privrednog razvoja. Te podsticaje, prvenstveno, treba usmeriti na područja infrastrukturnog opremanja, stimulisanja domaćih i stranih investitora za ulaganja u turizam, uvođenja međunarodnih standarda koji opredeljujuće deluju na kvalitet turistčkog proizvoda, primenu savremenih informacionih i drugih tehnologija i bolju promociju turističkih resursa na turističkom tržištu.

2. Unapređivanjem organizovnosti na svim nivoima donošenja odluka, bolju saradnju javno - privatnog sektora, bolju organizovanost turističke privrede i njenu jaču povezanost sa privrednim delatnostima koje učestvuju u formiraju turističkog proizvoda (trgovina, proizvodnja organski zdrave hrane, saobraćaj, ribarstvo, vinogradarstvo, zanatstvo, komunalne delatnosi i dr.).

Ovo zahteva značajno jaču ulogu menadžmenta turističkih destinacija, specijalizovanih javnih preduzeća za razvoj turizma i asocijacija turističke privrede, njihovu edukaciju na svim nivoima, edukaciju zaposlenih u svim segmentima ove delatnosti i potpuno obezbeđenje informatičke podrške razvoju turizma kroz uspostavljanje jedinstvene turističke statistike (smeštajnih kapaciteta, turističkog prometa i deviznog priliva) sa svetski uporedivim parametrima.

\section{MERE ZA PODSTICANJE RAZVOJA TURIZMA ${ }^{3}$}

Dinamičniji razvoj turizma, koji bi mogao biti snažna poluga ukupnog privrednog rasta, zahteva podršku u sledećim područjima:

3 Polazna osnova za izradu Mera za podsticanje razvoja turizma su radni materijali "Program mera i aktivnosti za ostvarivanje ciljeva Strategije razvoja turizma Srbije do 2025" i "Ključni elementi infrastrukture u prioritetnim turističkim destinacijima”, koji su autori ovog teksta pripremili za izradu navedenog dokumenta. 
1) dogradnja i unapređenje zakonske regulative i njeno usaglašavanje sa evropskim standardima,

2) unapređenje i razvoj saobraćajne, turističke, komunalne i ostale infrastrukture,

3) stimulisanje ukupne investicione aktivnosti,

4) vođenje stimulativne fiskalne politike,

5) podsticanje razvoja inostranog i domaćeg turizma.

\section{Uspostavljanje institucionalno - pravnog okvira za dalji razvoj turizma}

Ključne aktivnosi nosilaca turističke politike u domenu poboljšanja zakonske regulative u oblasti turizma mogće je ostvariti kroz:

- Unapređenje (dogradnja) zakonske regulative kojom se uređuje privređivanje turističke delatnosti. Kvalitetna i usklađena zakonodavna infrastruktura je preduslov uspešnog upravljanja turističkim razvojem. Poslovanje ove delatnosti uređeno je brojnim zakonskim, podzakonskim i dugim akatima za čije su predlaganje i sprovođenje zaduženi različiti organi i organizacije državne uprave. Radi se, pre svega, o onim zakonima koji direktno uređuju poslovanje ove oblasti, kao što je Zakon o turizmu, zatim set Zakona iz oblasti zaštite životne sredine, čijim rešenjima treba obezbediti efikasniju ekološku zaštitu i unapređenje turističkih prostora, Zakon o banjama, Zakon o nacionalnim parkovima, Zakon o planiranju i izgradnji i dr. Od značaja za ovu oblat su izakoni o: zaštiti i očuvanju kulturnih dobara, šumama, vodama, zaštiti potrošača i dr. Rešenja u ovim propisma su neusklađena, zastarela i nedorečena, pa kao takva otežavaju njihovo sprovđenje, što nameće potrebu nihove dogradnje, odnosno međusobne usklađenosti i usklađenosti sa kretanjima na savremenom turističkom tržištu;

- Završetak započetog procesa privatizacije hotelsko - ugostiteljskih preduzeća (hotela u sastavu SUP-a, vojske, javnih preduzeća, RHC i drugih hotelsko ugostiteljskih preduzeća koja nisu završila ovaj proces poput hotela "Slavija", UP "Vranje", UP "Evropa" Surdulica i dr.) i ostalih oblika transformacije kroz:

- dogradnju postojeće zakonske regulative vezane za utvrđivanje porekla sredstava, preciziranje rokova za privatizaciju, veću ulogu matičnog ministarstva, kontrolu izvršenja ugovora o kupoprodaji, pre svega u delu izvršenja investicionog programa, i dr.;

- rešenje statusa hotela koji zbog neadekvatne privatizacije i nerešenih imovinsko pravnih odnosa već duže vreme ne rade ili delimično rade (hotel "O Zone", hotel "Zelenkada", HTP "Fontana", hotel "Balkan", hotel "Prag", hotel "Prezident", hotel "Patrija" i dr.).

- Donošenje regulacionih planova koji će obezbediti da se razvoj planske dokumentacije sa master i prostornih planova prebaci na regulacione planove i planove marketinga i konkurentnosti koji su do sada vrlo retko rađeni. Tim planovima treba opredeliti lokacije na prioritetnim turističkim destinacijama za izgradnju novih kvalitenih hotela više i visoke ka- tegorije i novih turističkih sadržaja sa orijentacijom zaokruživanja već postojećih turističkih centara, a ne otvarenja novih sa nepotpuno uređenom infrastrukturom, turističkim sadržajima i neadekvatnim ljudskim resursima. Ovo neminovno vodi ograničavanju i zaustavljanju neplanske (divlje) gradnje i neplanskog razvoja turističkih kapaciteta uz harmonizaciju razvoja smeštajnih kapaciteta i drugih sadžaja.

- Dogradnju i unapređenje propisa koji će dovesti do značajnijeg smanjena sive ekonomije (uvođenje nelegalnog poslovanja u legalne tokove), koja je u oblasti ugostiteljstva dostigla kritičnu tačku kroz:

- pooštravanje kaznenih normi u domenu radnog zakonodavstva kroz jačanje uloge inspekcijskih službi i oštro sankcionisanje kršenja propisa; unapređenje zaštite korisnika turističkih usluga; efikasniju kontrolu sprovđenja propisa; izgradnju sistema upravljanja informacijama i kvalitetom.

\section{Unapređenje i razvoj saobraćajne, turističke, komunalne i ostale infrastrukture}

Unapređenje i razvoj ukupne infrastrukture treba da se ostvaruje kroz realizaciju prostorno - planskih dokumenata prema prioritetnim turističkim destinacijama (Službeni glasnik RS, 2010) u sledećim pravcima:

- Poboljšanje postojeće i izgradnju nove saobraćajne infrastrukture prema glavnim turističkim centrima (Zlatibor, Kopaonik, Stara planina, Vlasina, Vrnjačka Banja, Golija, Tara, Divčibare...) i mestima u okviru turističkih destinacija, što zahteva rekonstrukciju postojeće i izgradnju dela nove putne mreže, aerodroma za sletanje manjih aviona (Ponikve, Sombor, Morava), mostova, pristupnih puteva, modernizaciju železničkih pruga i pristupnih puteva prema železničkim stanicama, unapređenje plovnog saobraćaja i uređenje rečnog priobalja;

- Poboljšanje komunalne infrastrukture u turističkim centrima, rekonstrukcija postojeće i izgradnja nove vodovodne i kanalizacione mreže u skladu sa prioritetima utvrđenim regulacionim i detaljnim planovima;

- Razvoj i unapređenje turističke infrastrukture (kompletiranje i izgradnja sportskih objekata, tematskih parkova, bazena, golf terena i sl., unapređenje turističke signaliazcije, uređenje javnih površina unutar turističkih mesta, širenje mreže pešačkih i biciklističkih staza, otvaranje zanatskih i umetničkih radionica (kolonija) koje bi radile i prodavale suvenire, delikatesne stvari i sl. turistima, otvaranje novih i osavremenjavanje postojećih turističkih informativnih centara, trgovinskih i ugostiteljskih radnji i dr. u skladu sa opredeljenjima iz master i prostornih planova pojedinih turističkih destinacija);

- Stvararanje skladnog ambijenta između arhitekture i prirodno - kulturnog ambijenta uz zaštitu kulturnog nasleđa, zaustavljanje degradacije, revitalizaciju i uređenje prostorno kulturno - istorijskih celina, kako onih proglašenih, tako i onih koje to nisu, a posebno starih gradskih jezgara (Beograd, Novi Sad, 
Subotica, Sombor, Niš) i arhitektonsko usaglašavanje novoplaniranih objekata u tim prosorima sa postojećom arhitekturom. U tom pravcu sredstva pristupnih i drugih fondova EU i dugih međunarodnih finansijskih institucija prioritetno treba usmeravati na zaštitu prirodnih i kulturnih resursa i izgradnju turističke infrastrukture, pre svega u zaštićenim prostorima. Zaštita ovih prostora, inače je u prioritetu finansiranja regionalnih projekata iz fondova EU, a Srbija raspolaže brojnim zaštićenim prostorima i nije u stanju da ove projekte finansira sopstvenim sredstvima.

\section{Podsticanje investicione aktivnosti u turizmu}

Investicije u turizam u ukupnim investicijama u prethodnom periodu u Srbiji uglavnom su pratile udeo sektora u BDP-u, što znači da na ovaj sektor privređivanja u Srbiji otpada oko 1\% ukupnih investicija (RZS, 2014). Težnja za stvaranjem uslova da turizam bude jedan od pokretača privrednog razvoja nameće kao neophodnost jačanje investicionih aktivnosti radi postizanja značajnih efekata turističkog razvoja. Uvažavajući budžetska ograničenja, ali uz očekivano povećavanje interesovanja za ulaganja u Srbiju, rešenje je moguće naći kroz:

- Povećanje i restrukturiranje javnih investicija u turizmu, kao i aktivnija politika koja će dovesti do značajnog povećanja inostranih investicija u ovom sektoru. U tom smislu neophodno je godišnje održavati barem jednu turizmu posvećenu investicionu konferenciju, odrediti instituciju koja će biti zaduženju za informisanje potencijalnih investitora za ulaganja u ovu oblast (uslovi za ulaganja, podsticaji i sl.) i uraditi Kataloga projekata za ulaganja u turizam;

- Obezbeđenje projekata koji mogu koristiti sredstava pristupnih i drugih fondova EU i drugih finansijskih instiitucija, kao što su:

projekti na Dunavu kao jednom od ključnih razvojnih projekata EU, pri čemu su tržišni potencijal i atrakcijska baza za razvoj ovog proizvoda neosporni (European Movement in Serbia, 2015), izgradnja turističke infrastrukture, pre svega u zaštićenim prostorima, jer je zaštita ovih prostora u prioritetu finansiranja regionalnih projekata iz fondova EU, a Srbija raspolaže brojnim zaštićenim prostorima i nije u stanju da ove projekte finansira sopstvenim sredstvima;

- Davanje zemljišta bez naknade (koncesije) investitorima za ulaganja u turističku infrastrukturu, uz smanjenje poreskih, komunalnih i drugih dažbina (oslobađanje od plaćanja poreza na dobit ostvarenu po osnovu prihoda od predmeta koncesije na određeni rok i dr.);

- Obezbeđenje povoljnijih kredita za izgradnju smeštejnih kapaciteta (soft loans) na prioritetnim lokacijama (gde je urađena kompletna planska dokumentacija). Radi se o instrumentu direktnog podsticanja privatnih investitora sa kamatnom stopom od $1 \%$ na godišnjem nivou na period do 84 meseca po isteku odloženog roka u trajanju od 12 meseci. Ovi krediti u dosadašnjem periodu nisu u dovoljnoj meri korišćeni zbog ročnosti, ali treba nastaviti sa njihovim odobravanjem (uz odgovarajuće relaksiranje rokova) i to za: turističku infrastrukturu, izgradnju, rekonstrukciju i uređenje hotelskih i drugih smeštajnih objekata,nabavku i adaptaciju plutajućih objekata, prevoznih i rekreativnih sredstava namenjenih posetiocima i turistima,dizajn, pripremu za proizvodnju i proizvodnju turističkih suvenira (Turizam i putovanja, 2013);

- Obezbeđenje finansijskih i drugih oblika podsticaja i olakšica za ulaganja u hotelske kapacitete viših i visokih kategorija na prioritetnim lokacijama (poreske olakšice, smanjenje komunalnih dažbina na zemljište uključujući i dažbine na uvoz opreme i rezervnih delova za potrebe turisičke privredei dr.) (Službeni glasnik RS, br. 48/2010) i kapitalne investicije u turističkim centrima u slučaju da se kroz takve projekte obezbeđuje otvaranje značajnog broja novih radnih mesta.U tom kontekstu posebno je bitno zadržavanje postojećih rešenja vezano za:

- Pravo na oslobađanje od plaćanja poreza na dobit u periodu od 10 godina poreskom obvezniku koji uloži više cca. od 4 mil. evra (po važećem zakonu 6 miliona evra) i u periodu ulaganja dodatno zaposli na neodređeno vreme najmanje 100 lica,

- Pravo na oslobađanje od plaćanja poreza na dobit u periodu od 5 godina poreskom obvezniku, koji obavlja delatnost na području od posebnog interesa za Republiku, pod uslovom da je u osnovna sredstva uložio iznos veći od cca. 70 hiljada evra i da u periodu ulaganja obveznik dodatno zaposli na neodređeno vreme najmanje 5 lica;

- Obezbeđenje sredstva za subvencije (bespovratna sredstva i povoljniji krediti) za podsticanje razvoja kvaliteta turističke ponude određenih turističkih mesta i prostora (uključujući i razvoj ruralnih područja) uz striktno pridržavanje kriterijuma na bazi kojih se sredstva i dodeljuju i kontrolu njihovog utroška (Službeni glasnik RS, 2013).

\section{Vođenje stimulativne fiskalne politike}

Fiskalni nameti (porez na dobit, porez na dodatnu vrednost i druga opterećenja) značajno su veći nego u zemljama okruženja i predstavljaju veliki teret u poslovanju ove delatnosti. Stopa poreza na dobit povećana je sa $10 \%$ (bila među najnižim u okruženju) na $15 \%$. Stopa PDV na smeštaj povećana je sa $8 \%$ na $10 \%$ i veća je nego kod zemalja u okruženju (Hrvatska 10\%, Slovenija 8,5\%, Crna Gora 7\%, Bugarska 7\%), dok je stopa PDV-a na hranu i piće sa $18 \%$ povećana na $20 \%$.

U funkciji povećanja konkurentnosti turizma, neophodno je kontinuirano pratiti efekte postojećih fiskalnih opterećenja i sagledavati mogućnosti njihovog smanjenja (posebno kada je u pitanju: PDV na usluge smeštaja koje koriste inostrani turisti, porez na dobit, porez na zarade i druga primanja, doprinos na zarade, oslobađanje od plaćanja komunalnih i drugih davanja i dr.) ili ukidanja. Primera radi agencijama, hotelima ili drugim organizatororima kongresa ili dugih skupova, koji organizovano dovode inostarne turisteu našu zemlju, uz njihovu obavezu da ostvare sinergiju sa ostalim delatnostima (poljoprivreda, trgovina, zanatstvo i dr.), kako bi se osigurao kvalitet po konkurentnim cenama. 


\section{Stimulisanje razvoja inostranog turizma}

Nacionalni turistički marketing i menadžment, pre svega zbog nedovoljnog budžeta, još uvek nisu na potrebnom konkurentskom nivou pa se u tom segmentu uz manje budžetske impulse i jači upravljački angažman mogu napraviti značajniji efekti i u kraćem roku. Taj zaokret moguće je obezbediti kroz:

1) izdvajanje većeg iznosa sredstava za promociju turističke ponude Srbije u inostranstvu povećanjem turističkog budžeta za promociju u iznosu od $1 \%$ od ostvarenog deviznog priliva od turizma u predhodnoj godini, što je i preporuka UNWTO;

2) osnivanje mreže predstavništava sa predstavništvima nacionalnog avioprevoznika, PKS i drugim organizacija na ciljim turističkim tržištima (Čerović, 2002, str. 181);

3) stimulisanje prodaje robe domaćeg porekla stranim turistima kroz:

- obavezu slobodnih carinskih prodavnica (DFŠ) da u svojim prodavnicama drže najmanje $20 \%$ robe domaćeg porekla,

- povraćaj dela PDV (10 ili 20\%) na kupljenu domaću robu (TAX FREE) prilikom izlaska iz zemlje uz odgovarajuću dokumentaciju (REF i fakturu),

- simulisanje turisičkih agencija koje dovode strane turiste u Srbiju.

\section{Podsticanje razvoja domaćeg turizma}

U cilju intezivnijeg razvoja domaćeg turizma i boljeg korišćenja smeštajnih kapaciteta u turističkim mestima neophodno je:

- izvršiti disperziju školskih raspusta prema regionima (okruzima), kao i izvršiti preusmeravanje đačkih ekskurzija prema nacionalnim (ili regionalnim) turistčkim centrima i njihovo edukativno - programsko osmšljavanje prema nastavnim programima,

- obezbediti dotacije hotelima i drugim smeštajnim objektima za boravak turista u njima tokom (manji iznos sredstava) i izvan glavne turističke sezone (veći iznos sredstava),

- obezbediti raznovrsne "instant-programe" učenja stranih jezika, plesa, folklora, sportskih veština, kulinarstva i dr. (Čerović, 2007, str. 184),

- usklađivanje infrastrukture, javnih službi, usluga, rekreacije i sporta sa istovremenim potrebama stalnih stanovnika i turista.

\section{REZIME}

Srbija nema prepoznatljiv imidž turističke destinacije jer, osim Beograda, Kopaonika i još nekih drugih destinacija, ne nudi međunarodnom tržištu prepoznate proizvode. Ništa povoljnija situacija nije ni na domaćem tržištu, koje kontinuirano opada (posebno u banjama) zbog smanjenja kupovne moći, neadekvatne ponude, ali i liberalizacije uslova putovanja. Inostrano tržište raste uglavnom u segmentu individualnih i poslovnih putovanja.

S obzirom da se ulazi u fazu ozbiljnih privrednih reformi za očekivati je da će Srbija u narednom periodu više pažnje posveti ovoj delatnosti i stimulativnim merama podstaći njen razvoj čime bi se obezbedilo:

- povećanje izgradnje hotelskih kapaciteta, posebno onih sa višom kategorijom i njihov veći udela u ukupnim smeštajnim kapacitetima; nastavak tendencije povećanja inostranog turističkog prometa na nivou i znatno dinamičniji rast domaćeg turističkog prometa (10-12\%), što bi u dogledno vreme (5-7 godina) dovelo do udvostručenja ukupnog turističkog prometa, veće iskorišćenosti kapaciteta, povećanja deviznog priliva, povećanja broja zaposlenih u ovoj delatnosti i delatnostima komplementarnim turizmu, uz zadržavanje odliva mlađeg stanovništva i povećanog udela turizma u BDP-u. Na nosiocima poslovne i turističke politike je realizovanje ovih pretpostavki.

\section{LITERATURA}

Barjaktarović, D. (2008). Menadžment hotelskog preduzeća na savremenom turističkom tržištu. Beograd: Univerzitet Singidunum.

Barjaktarović, D. (2013). Restoratersko poslovanje. Beograd: Univerzitet Singidunum.

Čerović, S. (2002). Strategijski menadžment turističke privrede Srbije. Beograd: Želnid.

Čerović, S. (2007). Podsticanje razvoja turizma Srbije. U: Ekonomska politika u 2006. godini (str. 303-313). Beograd: Ekonomski fakultet.

Čerović, S., Barjaktarović, D., \& Knežević, M. (2015). Radni materijal "Program mera i aktivnosti za ostvarivanje ciljeva nove Strategije razvoja turizma Srbije do 2025”. Beograd: Ministarstvo turizma, trgovine i telekomunkiacija.

Čerović, S., Barjaktarović, D., Knežević, M., \& Pavlović, D. (2015). Ključni elementi infrastrukture u prioritetnim turističkim destinacijima, Prilog za izradu Strategije razvoja turizma do 2025. godine. Beograd: Ministarstvo turizma, trgovine i telekomunkiacija.

European Movement in Serbia. (2015). Dunav-Najjača veza sa Evropskom unijom. Preuzeto 5. juna 2015. sa http:// www.emins.org/sr/aktivnosti/projekti/dunav/o_dunavu.pdf

Narodna banka Srbije. (2015). Statistički bilten. Preuzeto 5. juna 2015. sa http://www.nbs.rs/internet/cirilica/90/ sb.html

Republički zavod za statistiku. (2014). Statistički gošnjak Republike Srbije. Preuzeto 5. juna 2015. sa http://pod2. stat.gov.rs/ObjavljenePublikacije/God/SGS2014.pdf

Službeni glasnik Republike Srbije. (2006). Strategija razvoja turizma Republike Srbije. Službeni glasnik Republike Srbije, br. 91/2006. Preuzeto 5. juna 2015. sa http://mtt.gov. rs/download/3/Strategija\%20razvoja\%20turizma,cir.pdf

Službeni glasnik Republike Srbije. (2010). Uredba o vrsti, količini i vrednosti robe na koju se ne plaćaju uvozne dažbine. Službeni glasnik Republike Srbije br. 48/2010.

Službeni glasnik Republike Srbije. (2010a). Zakon o prostornom planu Republike Srbije od 2010. do 2020. godine. Službeni glasnik Republike Srbije br. 88/2010.

Službeni glasnik Republike Srbije. (2013). Uredba o uslovima i načinu dodele i korišćenja kreditnih sredstava za podsticanje kvaliteta turističke ponude. Službeni glasnik Republike Srbije br. 22/2013. 
Todosijević, R. (2004). Faktori izbora strategijske opcije za turističku destinaciju. Marketing hotelske kuće: više od realizacija / V naučno-stručni simpozijum Hotelska kuća 2004 (str. 82-103). Beograd: Poslovno udruženje hotelsko-ugostiteljske privrede "Hores".

Turizam i putovanja. (2013). Krediti za turizam i ugostiteljstvo po odličnim sulsovima. Preuzeto 5. juna 2015. sa http://www.turizamiputovanja.com/krediti-za-turizamugostiteljstvo-po-odlicnim-uslovima/

Unković, S., \& Zečevć, B. (2012). Ekonomika turizma. Beograd: Ekonomski fakultet.
Weaver, D., \& Lawton, L. (2010). Tourism Management. Milton: Wiley \& Sons.

WTTC. (2015). Economic impact research. Preuzeto 5. juna 2015. sa http://www.wttc.org//media/files/reports/economic\%20impact\%20research/countries\%202015/serbia2015.pdf).

YUTA. (2015). Turističke agencije. Preuzeto 5. juna 2015. sa www.yuta.rs/sr/yuta/turisticke_agencije.asp.

\section{SUPPORT TO TOURISM DEVELOPMENT AS A FACTOR OF SERBIAN TOURISM DESTINATION COMPETITIVENESS}

\begin{abstract}
:
Due to its exceptional natural, geographic, cultural - historical, climate and other resources, Serbia boasts highly favorable conditions for development of those forms of tourism that will represent the dominant future movements in international relations and offer possibilities for meeting the diverse requirements and needs of modern tourists. Also, the achieved level of accommodation and other facilities concerning tourism infrastructure provide a good basis for significant valorization of such resources and adequate involvement of our country in international tourist flows, including faster development of domestic tourism. This paper shows that tourism in Serbia, in terms of all relevant indicators (foreign consumption, realized tourist traffic, employment, contribution to GDP, exports of goods and services, investment, etc.), is significantly lagging behind compared to resource and market opportunities for its development, which inevitably requires a more active role of the state in taking incentive measures, in order to initiate its multiplicative component and development of the overall Serbian economy. Having that in mind, the principal purpose of this paper is to highlight the key activities of the state and other entities responsible for creating and implementing tourism policies that would lead to valorization of Serbian tourism resources.
\end{abstract}

\section{Key words:}

tourism,

strategy,

development,

resources,

incentives. 